НАЦІОНАЛЬНО-ПАТРІОТИЧНЕ ВИХОВАННЯ МАЙБУТНІХ ПОЛІЦЕЙСЬКИХ НА ЗАНЯТТЯХ З УКРАЇНСЬКОЇ МОВИ ПРОФЕСІЙНОГО СПРЯМУВАННЯ

\title{
NATIONAL-PATRIOTIC EDUCATION OF FUTURE POLICE IN UKRAINIAN LANGUAGE CLASSES FOR PROFESSIONAL PURPOSES
}

у статті обгрунтовано актуальність питань, пов'язаних із національно-патріотичним вихованням майбутніх поліцейських. Це доведено, по-перше, політичними умовами у країні, через які Україна змушена відстоювати свою свободу та територіальну цілісність, і для цього потрібні справжні патріоти. По-друге, реформування правоохоронних органів відповідно до міжнародних стандартів вимагає якісної підготовки поліцейських до профресійноі діяльності, у якій пріоритетного значення набуває національно-патріотичне виховання.

Метою статmі є дослідження шляхів здійснення національно-патріотичного виховання поліцейських на заняттях з української мови професійного спрямування. Для цього потрібно формувати мотивацію для вивчення української мови, удосконалювати мовленнєву культуру, підвищувати загальнокультурний рівень майбутніх поліцейських, виховувати в них почуття національної гідності й відповідальності за свою країну та народ, патріотичних почуттів, поглядів, переконань.

З'ясовано, що з метою фрормування мовленнєвої культури доцільно на заняттях 3 української мови професійного спрямування застосовувати сукупність вправ і завдань різних видів: фонетичних, лексичних, граматичних, стилістичних, а також інтегрованих вправ.

На заняттях з української мови профресійного спрямування в закладі вищої освіти потрібно враховувати специфріку діяльності поліцейських, наповнюючи заняття відповідним змістом. Під час мовленнєвої підготовки майбутніх поліцейських ми пропонуємо забезпечувати професійну спрямованість навчання, що передбачає моделювання різноманітних ситуацій майбутньоі профресійної діяльності, які потребують розвинених мовленнєвих умінь і навичок (мовленнєві ситуації, комунікативно-ситуативні завдання), застосування методів активного навчання (ділових, сюжетнорольових ігор, аналізу конкретних профресійних ситуацій) з метою стимулювання їхньої мовленнєвої (комунікативноі) активності.

3 метою виховання свідомого громадянина, патріота, котрий має потребу та вміння жити у громадському суспільстві, бути культурною та духовно і фрізично досконалою людиною, доцільно залучати студентів до вивчення національної культури й духовності, сприяти фрормуванню національних світоглядних позицій, ідей, поглядів, переконань на основі цінностей вітчизняної та світової культури.
Ключові слова: національно-патріотичне виховання, мовленнєва культура, позаауди торна робота, комунікативно-ситуативні завдання, ділові ігри.

The article proves the relevance of issues related to the national-patriotic education of future police officers. This is proved, first of all, by the political conditions in the country, due to which Ukraine is forced to defend its freedom and territorial integrity, and this requires real patriots. Secondly, the reform of law enforcement agencies in accordance with international standards requires highquality training of police officers for professional activities, in which national-patriotic education becomes a priority. The purpose of the article is to study the ways of nationalpatriotic education of police officers in Ukrainian language classes for professional purposes.

For this purpose, it is necessary to form motivation for learning the Ukrainian language, improve speech culture, raise the general cultural level of future police officers, cultivate a sense of national dignity and responsibility for their country and people, patriotic feelings, views and beliefs.

It was found out that in order to form a speech culture; it is expedient to use a set of exercises and tasks of different types in professional Ukrainian language classes: phonetic, lexical, grammatical, stylistic, as well as integrated exercises.

In the classes on the Ukrainian language of professional orientation in the institutions of higher education, it is necessary to take into account the specifics of the police activity, filling the classes with appropriate content. During the speech training of future police officers, we propose to provide professional orientation of training, which involves modeling various situations of future professional activity that require developed speech skills (speech situations, communicative-situational tasks), the use of active learning methods (business, story-role games, analysis of specific professional situations) in order to stimulate their speech (communicative) activity.

In order to educate a conscious citizen, patriot, who has the need and ability to live in civil society, to be culturally and spiritually and physically perfect person, it is advisable to involve students in the study of national culture and spirituality, to promote the formation of national worldviews, ideas, views, beliefs, values of national and world culture.

Key words: national-patriotic education, speech culture, extracurricular work, communicative-situational tasks, business games. гуманітарних дисциплін
Харківського національного

університету внутрішніх справ патріотичне виховання, що передбачає виховання патріотизму, активної громадянської позиції, відданості загальнодержавній справі зміцнення країни. 
Крім того, інтеграція України у європейський простір вимагає гарантування повноцінного фрункціонування інститутів, що забезпечують верховенство права, здійснюють захист прав і свобод громадян. Виконання цих орункцій покладено на органи правопорядку. Реформування правоохоронних органів відповідно до міжнародних стандартів забезпечення прав і свобод у різних сорерах життєдіяльності людини має забезпечити еоективне фрункціонування інституту поліції в Україні. Це вимагає якісної підготовки поліцейських до професійної діяльності, у якій пріоритетного значення набуває національно-патріотичне виховання.

У Стратегії національно-патріотичного виховання зазначається: «В Україні національнопатріотичне виховання $є$ одним із пріоритетних напрямів діяльності держави та суспільства щодо розвитку національної свідомості на основі суспільно-державних (національних) цінностей (самобутність, воля, соборність, гідність), фрормування у громадян почуття патріотизму, поваги до Конституції та законів України, соціальної активності та відповідальності за доручені державні та громадські справи, готовності до виконання обов'язку із захисту незалежності та територіальної цілісності України, сповідання європейських цінностей» [8].

Аналіз основних досліджень і публікацій. Багато наукових досліджень присвячені питанням, пов'язаним із національно-патріотичним вихованням. Так, ці питання були предметом розгляду фрілософрів (М. Антонець, А. Бойко, В. Бичко, М. Євтух, О. Забужко, П. Кононенко, В. Москалець, І. Надольний, Л. Сохань, М. Стельмахович), психологів (Б. Ананьєв, І. Бех, П. Блонський, П. Вербицька, Л. Виготський, П. Ігнатенко, Г. Костюк, О. Леонтьєв, О. Петровський, А. Погребний, В. Поплужний, Ю. Руденко, К. Чорна, О. Шестопалюк, П. Якобсон), педагогів (Г. Ващенко, Б. Грінченко, М. Грушевський, А. Дістервег, М. Драгоманов, О. Духнович, Я. Коменський, Я. Корчак, А. Макаренко, І. Огієнко, С. Русова, В. Сухомлинський, К. Ушинський).

Виділення не вирішених раніше частин загальної проблеми. Незважаючи на велику кількість робіт, присвячених питанню національнопатріотичного виховання майбутніх поліцейських, ця проблема потребує ретельного вивчення й удосконалення. Усе це зумовило вибір теми нашого дослідження.

Метою статті $€$ вивчення шляхів здійснення національно-патріотичного виховання поліцейських на заняттях з української мови професійного спрямування.

Виклад основного матеріалу. Вивчення курсу української мови має, крім освітньої, ще й виховну мету, що полягає у вихованні поваги до української мови, сприянні бажання знати українську мову, удосконалювати мовленнєву культуру, уважно ставитися до української культури, історії, науки, народних традицій.

3 цією метою потрібно фрормувати мотивацію для вивчення української мови, удосконалювати мовленнєву культуру, підвищувати загальнокультурний рівень майбутніх поліцейських, виховувати в них почуття національної гідності та відповідальності за свою країну та народ, патріотичних почуттів, поглядів, переконань.

Відзначаючи важливу роль мовленнєвої культури в житті кожної людини, Л. Введенська та Л. Павлова підкреслюють, що «оволодіння мистецтвом спілкування, мистецтвом слова, культурою усного й письмового мовлення» сьогодні необхідне для кожної людини незалежно від того, «яким видом діяльності вона займається чи буде займатися» [1, с. 4].

На основі аналізу наукової літератури можна зробити висновок про те, що мовленнєву культуру сприймають як інтегративну особистісну якість, яка відбиває спроможність людини здійснювати ефективну мовленнєву діяльність на основі врахування поставленої мети та наявної мовленнєвої ситуації, а також норм літературної мови.

Серед характерних комунікативних ознак мовленнєвої культури особистості головне місце посідають такі: правильність, точність, логічність, виразність, образність, багатство, різноманітність, доречність, стислість, ясність. Ці ознаки можуть виявлятися у процесі здійснення людиною різних видів мовленнєвої діяльності: слухання, читання, говоріння та письма.

У процесі педагогічної взаємодії зі студентами слід також ураховувати той фракт, що через історичні перипетії не всі українці вільно володіють українською мовою. Зокрема, мешканці західних регіонів країни у процесі спілкування часто використовують слова, запозичені з польської, румунської, угорської та інших мов, а представники південно-східних територій - русизми. Нерідко спілкування молодих людей із представниками їхнього ближнього оточення (друзі, батьки) негативно впливає на стан мовленнєвої культури особистості. У цьому разі викладачам важливо забезпечити максимально ефективний вплив на процес засвоєння теоретичних основ мовленнєвої культури студентів. Одним із ефективних шляхів вирішення цієї проблеми $є$ забезпечення опанування ними нормативних мовленнєвих засобів, вироблених практикою людського спілкування.

Ми погоджуємося з М. Пентилюк, яка уважає, що для розвитку й удосконалення мовленнєвої культури учнів слід підбирати сукупність вправ і завдань різних видів: фонетичних, лексичних, граматичних, стилістичних. Так, вправи та завдання 3 першої визначеної групи включають вправи, що передбачають виразне читання й аудіювання текстів різних стилів, типів і жанрів мовлення, вправи 
на правильне наголошення слів, інтонування висловлювань, дотримання норм милозвучності мови, добір фронетичних варіантів і складання 3 ними речень, редагування текстів відповідно до евфронічності їх звучання, аналіз чергування голосних і приголосних звуків. Прикладом можуть бути такі завдання: прочитати текст, проаналізувати інтонаційну особливість речень; охарактеризувати стилістичні особливості мовних одиниць; визначити стиль, тип і жанр мовлення.

Як нагадує авторка, для красивого, доречного та правильного формулювання думок і висловлювань людина має постійно збагачувати свій активний словниковий запас, що є однією 3 важливих передумов результативного опанування мовленнєвою культурою. Багатий словниковий запас $є$ також важливим фрактором успішної мовленнєвої комунікації. М. Пентилюк чільне місце в системі мовленнєвих вправ відводить лексичним вправам і завданням. До цієї групи належать завдання та вправи, спрямовані на з'ясування семантики слова, його основних ознак, ознайомлення зі словниковим складом української мови, сорерою вживання різних лексичних шарів (наприклад, такого типу: користуючись тлумачним словником рідної мови, з'ясуйте, які значення мають запропоновані слова...).

Третя визначена група містить граматичні вправи та завдання. До них належать, наприклад, такі завдання: аналіз стилістичних особливостей словотвору; доцільне використання в тексті різних словотворчих засобів, частин мови, граматичних синонімів; виправлення стилістичних помилок граматичного характеру; конструювання речень і текстів різних стилів, типів і жанрів; визначення фрункцій спілкування, мовленнєвої ситуації перед створенням висловлювань; відповідний вибір синтаксичної конструкції, синонімічні заміни різних синтаксичних одиниць, редагування речень щодо стилістичного оформлення, взаємозаміна синтаксичних конструкцій і встановлення їхньої стилістичної специфріки, зіставлення текстів різних стилів у зв'язку із синтаксичною стилістикою.

Стилістичні вправи насамперед передбачають аналіз текстів різних стилів, типів і жанрів мовлення та конструювання текстів відповідної стилістичної спрямованості залежно від ситуації спілкування; аналіз стилістичних значень, відтінків і фрункцій слів; редагування текстів із боку їх стилістичного офрормлення; стилістичний експеримент; стилістичні завдання творчого характеру тощо. За словами М. Пентилюк, таку роботу слід проводити на базі стилістично диференційованих текстів, порівнюючи стилістичне значення мовних категорій у різних стилях і засвоюючи значення стилістичних понять через зіставлення лінгвістичного тлумачення їх сутності зі стилістичним тлумаченням.
На думку дослідниці, існують також різні види інтегрованих вправ. Так, лексико-граматичні вправи використовують для засвоєння та закріплення знань із граматики та повторення теоретичних відомостей із лексики, збагачення словника, розвитку мовлення учнів. Лексико-стилістичні вправи передбачають вироблення в учнів навичок правильно користуватися словом у певному стилі мовлення, аналіз й усунення лексико-стилістичних помилок. Доречним також є поєднання вивчення лексико-семантичної структури мови 3 аналізом стилістичних можливостей цих мовних одиниць і 3 подальшим введенням їх у власні висловлювання. Прикладом таких вправ може бути аналіз у тексті синонімів та антонімів, складання речень із такими мовними одиницями [6].

Отже, з метою фрормування мовленнєвої культури доцільно на заняттях з української мови професійного спрямування застосовувати сукупність вправ і завдань різних видів: фронетичних, лексичних, граматичних, стилістичних, а також інтегрованих вправ.

Як зазначено в науковій літературі, багато студентів, котрі засвоїли лінгвістичний матеріал, відчувають певні труднощі під час реалізації мовленнєвої практики. У процесі педагогічної взаємодії важливо забезпечити не тільки оволодіння студентами теоретичними основами мовленнєвої культури, а й навчити їх орієнтуватися в конкретних мовленнєвих ситуаціях, підбирати відповідно до них адекватні мовні засоби, правильно застосовувати невербальні мовні засоби (жести, міміку тощо). Це передбачає застосування різних активних й інтерактивних методів навчання. О. Горошкіна конкретизує, що учням необхідна «систематична цілеспрямована мовленнєва практика, яка ґрунтується на вмінні вибирати потрібні слова, конструкції 3 урахуванням умов спілкування» [2, с. 16]. Для цього слід застосовувати різні активні методи навчання.

Н. Луценко також зазначає, що мовленнєве спілкування відбувається у процесі комунікативно-мовленнєвої діяльності. Для її успішного здійснення молода людина має засвоїти не тільки відповідні знання, а цілу низку найважливіших мовленнєвих умінь, зокрема таких: уміння орієнтуватися в ситуації спілкування залежно від часово-просторових і змістових особливостей, соціальних ролей співрозмовників і їхніх взаємин, планувати мовленнєву поведінку залежно від статі, віку, соціальної ролі, фрізичного та психологічного станів співрозмовника, добору лексичних засобів і граматичних фрорм, довільного керування невербальними засобами спілкування; уміння правильно використовувати вербальні й невербальні прийоми вступу до мовленнєвого контакту, підтримувати й розвивати діалогічну взаємодію, ввічливе й логічне завершення спілкування, здатність виявляти ініціативу 
у спілкуванні з дорослими й однолітками, знаходити в колі ровесників партнерів-співрозмовників, пропонувати тему розмови, спрямовувати їі в потрібне русло з урахуванням власних і спільних інтересів; уміння розв'язувати комунікативномовленнєві завдання завдяки добору адекватних комунікативній меті та проблемній ситуації засобів; уміння досягати комунікативної мети завдяки комплексному використанню мовленнєвих орорм і невербальних засобів, адресованих партнеруспіврозмовнику [5].

На нашу думку, на заняттях з української мови профресійного спрямування у ЗВО потрібно враховувати специфіку діяльності поліцейських, наповнюючи заняття відповідним змістом. Під час мовленнєвої підготовки майбутніх поліцейських ми пропонуємо забезпечувати професійну спрямованість навчання, що передбачає моделювання різноманітних ситуацій майбутньої професійної діяльності, які потребують розвинених мовленнєвих умінь і навичок (мовленнєві ситуації, комунікативно-ситуативні завдання), застосування методів активного навчання (ділових, сюжетно-рольових ігор, аналізу конкретних професійних ситуацій) із метою стимулювання їхньої мовленнєвої (комунікативної) активності.

Отже, застосування різних активних методів навчання сприятиме створенню умов для систематичної спрямованої мовленнєвої практики студентів, дасть можливість удосконалити низку мовленнєвих умінь.

3 метою здійснення національно-патріотичного виховання необхідно більш повно використовувати педагогічні можливості в окресленому напрямі - здійснювати позааудиторну роботу у 3 BO.

Як зазначено в науковій літературі, позааудиторна навчально-виховна робота порівняно 3 аудиторною має більш нерегламентований характер, оскільки вона жорстко не обмежена часовими, організаційними та змістовими вимогами. У процесі її здійснення викладач може керуватися насамперед суспільною потребою у фрормуванні мовленнєвої культури студентів та індивідуальними потребами, інтересами самих студентів. Крім того, важливо відзначити, що в позааудиторній діяльності провідну роль виконують самі студенти, це створює позитивні передумови для найбільш повного виявлення ними засвоєних мовленнєвих знань і вмінь, самостійності, ініціативності, а також творчого мислення.

Л. Кондрашова також звертає увагу на те, що в позааудиторній діяльності можна застосовувати більш широкий арсенал методів, фрорм, технологій навчання й виховання учнівської молоді, створюючи сприятливі передумови для активізації самостійної роботи учнів, залучати їх до розв'язання різних проблемних ситуацій, які сприяють вирішенню поставлених педагогічних завдань, активізують розвиток в особистості соціально значущих умінь, особистісних якостей шляхом залучення до різних видів практичної діяльності [4, с. 13].

На важливу роль позааудиторної діяльності у процесі орормування мовної особистості вказує С. Караман. За висновками автора, така діяльність сприяє поглибленню фрілологічних знань учнів, розвиває їхні мовленнєві вміння та творче мислення [3, с. 45].

Слід також зазначити, що система позааудиторної діяльності містить різні їі види. Зокрема, найбільший педагогічний ефект щодо фрормування мовленнєвої культури студентів спостерігають, коли простежується тісний взаємозв'язок між «суто» виховною позааудиторною діяльністю творчого характеру та іншими її видами: навчальною, навчально-дослідницькою й науково-дослідницькою [7, с. 74].

Позааудиторними заходами, спрямованими на підвищення мовленнєвої культури студентів, можуть бути конкурси знавців української мови, вечори поезії, конкурси читців віршів, есе та інших написаних студентами творів.

Отже, проведення навчально-виховної позааудиторної роботи сприяє фрормуванню мовленнєвої культури студентів, їхньої самостійності, ініціативності, творчого мислення.

Крім того, з метою виховання свідомого громадянина, патріота, котрий має потребу й уміння жити у громадському суспільстві, бути культурною та духовно і фрізично досконалою людиною, доцільно залучати студентів до вивчення національної культури й духовності, сприяти фрормуванню національних світоглядних позицій, ідей, поглядів, переконань на основі цінностей вітчизняної та світової культури. Для цього слід через мову долучати студентів до національної історії, національної культури, глибинної сутності народного життя, поширювати інфрормацію про досягнення наших співвітчизників і їхній внесок у різні сорери: освіти, науки, культури, мистецтва, спорту.

Висновок. 3 метою здійснення національнопатріотичного виховання пропонуємо застосовувати сукупність вправ і завдань різних видів: фронетичних. лексичних, граматичних, стилістичних, а також інтегрованих вправ; використовувати активні методи навчання; використовувати навчальний матеріал, що сприятиме фрормуванню національних світоглядних позицій, ідей, поглядів, що містить цікавий матеріал із національної історії, культури, народного життя, сучасних досягнень українців у різних сорерах; здійснювати позааудиторну роботу.

3 метою здійснення національно-патріотичного виховання поліцейських доцільно розробити сис- 
тему вправ і завдань різних видів, систему рольових і ділових ігор, ситуативних завдань (активних методів навчання), під час яких студенти будуть набувати різноманітні мовленнєві навички; розробити цікаві позааудиторні заходи.

\section{БІБЛІОГРАФІЧНИЙ СПИСОК:}

1. Введенская Л.А. Риторика и культура речи. Ростов-на-Дону : Изд-во «Феникс», 2003. 544 с.

2. Горошкіна О.М. Методика навчання української мови в загальноосвітніх навчальних закладах III ступеня природничо-математичного профрілю : автореф. дис. ... канд. пед. наук : 13.00.02. Київ, 2005. 39 с.

3. Караман С.О. Позакласна робота з української мови. Українська мова і література в загальноосвітніх школах. 2004. № 9. С. 45-47.
4. Кондрашова Л.В. Внеаудиторная работа по педагогике в педагогическом институте. Киев, Одесса : Высшая шк. Головное изд-во, 1988. 160 с.

5. Луценко Н. Введение в лингвистику слова. Горловка : Изд. ГГПИИЯ, 2003. 144 с.

6. Методика навчання української мови в середніх навчальних закладах / за ред. М. Пентилюк. Київ : Ленвіт, 2005. 400 с.

7. Петриченко Л.О. Підготовка майбутнього вчителя початкової школи до інноваційної діяльності в позааудиторній діяльності : дис. ... канд. пед. наук : 13.00.04. Харків, 2007. 236 с.

8. Стратегія національно-патріотичного виховання: Указ Президента України 18 травня 2019 p. № 286/2019. URL: https://zakon.rada.gov.ua/ laws/show/286/2019\#Text (дата звернення: 15.03. 2021). 